\title{
The Central and Basolateral Amygdala Are Critical Sites of Neuropeptide Y/Y2 Receptor-Mediated Regulation of Anxiety and Depression
}

\author{
Ramon 0. Tasan, ${ }^{1}$ Ngoc Khoi Nguyen, ${ }^{2}$ Stefan Weger, ${ }^{3}$ Simone B. Sartori, ${ }^{2}$ Nicolas Singewald, ${ }^{2}$ Regine Heilbronn, ${ }^{3}$ \\ Herbert Herzog, ${ }^{4}$ and Günther Sperk ${ }^{1}$ \\ ${ }^{1}$ Department of Pharmacology, Medical University Innsbruck, 6020 Innsbruck, Austria, ${ }^{2}$ Department of Pharmacology and Toxicology, Institute of \\ Pharmacy and Center of Molecular Biosciences Innsbruck, University of Innsbruck, 6020 Innsbruck, Austria, ${ }^{3}$ Institute of Virology, Campus Benjamin \\ Franklin, Charité Universitätsmedizin Berlin, 12203 Berlin, Germany, and ${ }^{4}$ Neuroscience Research Program, Garvan Institute of Medical Research, \\ Darlinghurst, Sydney, New South Wales 2010, Australia
}

Anxiety is integrated in the amygdaloid nuclei and involves the interplay of the amygdala and various other areas of the brain. Neuropeptides play a critical role in regulating this process. Neuropeptide Y (NPY), a 36 aa peptide, is highly expressed in the amygdala. It exerts potent anxiolytic effects through cognate postsynaptic $\mathrm{Y} 1$ receptors, but augments anxiety through presynaptic $\mathrm{Y} 2$ receptors. To identify the precise anatomical site(s) of Y2-mediated anxiogenic action, we investigated the effect of site-specific deletion of the Y2 gene in amygdaloid nuclei on anxiety and depression-related behaviors in mice. Ablating the Y2 gene in the basolateral and central amygdala resulted in an anxiolytic phenotype, whereas deletion in the medial amygdala or in the bed nucleus of the stria terminalis had no obvious effect on emotion-related behavior. Deleting the Y2 receptor gene in the central amygdala, but not in any other amygdaloid nucleus, resulted in an added antidepressant-like effect. It was associated with a reduction of presumably presynaptic Y 2 receptors in the stria terminalis/bed nucleus of the stria terminalis, the nucleus accumbens, and the locus ceruleus. Our results are evidence of the highly site-specific nature of the Y2-mediated function of NPY in the modulation of anxiety- and depression-related behavior. The activity of NPY is likely mediated by the presynaptic inhibition of GABA and/or NPY release from interneurons and/or efferent projection neurons of the basolateral and central amygdala.

\section{Introduction}

Anxiety and depression are among the most prevalent disorders of the nervous system and impose a high social burden in industrialized countries (Kessler et al., 2005). The mechanisms in the brain that regulate mood and mood malfunction are still poorly understood. Classic neurotransmitters, such as GABA, serotonin, and noradrenaline, have been implicated in the integration of anxiety or depression (Millan, 2003). Drugs that interfere with these transmitter systems, such as the benzodiazepines and amine reuptake inhibitors, are among the most widely prescribed medications. The limited efficacy and serious side effects of these drugs, however, underscore the need for a better understanding of the mechanisms of action of current medications and the neural circuits that are involved in regulating mood and mood dysfunctions, as well as better approaches to the treatment of mood disorders.

\footnotetext{
Received Jan. 26, 2010; revised March 12, 2010; accepted March 21, 2010.

This work was supported by Austrian Science Fund Grants S10204 and S10202. We thank Anna Wieselthaler and Elke Kirchmair for technical assistance and Dr. Fred H. Gage for the rAAV-Cre vector.

Correspondence should be addressed to either Dr. Günther Sperk or Dr. Ramon Tasan, Department of Pharmacology, Medical University Innsbruck, Peter-Mayr Strasse 1a, 6020 Innsbruck, Austria, E-mail: guenther.sperk@ i-med.ac.at or ramon.tasan@i-med.ac.at.

DOI:10.1523/JNEUROSCI.0430-10.2010

Copyright $\odot 2010$ the authors $\quad 0270-6474 / 10 / 306282-09 \$ 15.00 / 0$
}

In recent years, a prominent role of various neuropeptides in integrating emotions emerged. Thus converging evidence indicates that neuropeptide Y (NPY), a highly conserved 36 aa peptide, exerts potent anxiolytic effects when injected into the amygdala of mice (Heilig et al., 1993). NPY knock-out (KO) mice exhibit a more anxious phenotype (Bannon et al., 2000), whereas intracerebral injection of the Y1 receptor agonist [ $\mathrm{Leu}^{31}$, Pro ${ }^{34}$ ] NPY results in less anxious behavior (Broqua et al., 1995). Partial deletion of Y1 receptors by Y1 antisense oligonucleotide increases anxiety (Wahlestedt et al., 1993), which suggests that the anxiolytic action of NPY is mediated by Y1 receptors. In contrast, Y2 receptors appear to mediate anxiogenic actions of NPY (Nakajima et al., 1998). Intracerebroventricular injection of the Y2-selective antagonist BIIE0246 (Bacchi et al., 2006), or genetic deletion of Y2 receptors (Tschenett et al., 2003), results in anxiolytic and antidepressant-like effects. These divergent effects of NPY mediated by $\mathrm{Y} 1$ and $\mathrm{Y} 2$ receptors can be explained by different receptor localization and function at synapses. Y1 receptors are postsynaptic receptors (Sosulina et al., 2008), whereas Y2 receptors are primarily presynaptic and are involved in the inhibition of NPY, GABA, or glutamate release.

Whereas an important role for amygdaloid nuclei in the NPYmediated modulation of emotional states is well supported, the precise anatomical sites of NPY action within the amygdala complex are not known. To investigate the location of NPY 
action, conditional $Y 2$ receptor knock-out $\left(Y 2^{\text {lox } / l o x}\right)$ mice were administered bilateral stereotaxic injections of a recombinant adeno-associated virus-based vector (rAAV), encoding a green fluorescent protein (GFP) fusion protein of Cre-recombinase (Cre), into different amygdaloid nuclei. Expression of Cre resulted in deletion of the Y2 receptor gene through flanking LoxP sites. We investigated behavioral patterns of anxiety and stress coping in mice that received $\mathrm{rAAV}$-Cre as compared to littermates that were injected at the same sites with a $\mathrm{rAAV}$ vector expressing GFP alone (rAAV-GFP). Our data indicate that Y2 receptor gene deletion in the central amygdala (CEA) or basolateral amygdala (BLA), but not in other sites of the amygdaloid complex, results in a profound reduction of anxiety and is associated with a loss of $\mathrm{Y} 2$ receptors at terminal areas of efferent projections of the CEA.

\section{Materials and Methods}

\section{Conditional Y2 receptor knock-out mice}

Experiments were conducted in adult male (10-16 weeks of age, 25-30 g) conditional Y2 receptor knock-out $\left(Y 2^{l o x / l o x}\right)$ mice, which were maintained on a mixed C57BL/6-129SvJ background (Sainsbury et al., 2002). Mice were housed in groups of three to five under standard laboratory conditions $(12 \mathrm{~h} / 12 \mathrm{~h}$ light/dark cycle starting at 7:00 A.M.; food and water ad libitum). After stereotaxic injection, mice were singly housed to assure optimal recovery from surgery. All procedures involving animals and animal care were conducted in accordance with international laws and policies (Guide for the Care and Use of Laboratory Animals, U.S. National Research Council, 1996; EEC Council Directive 86/609, OJ L 358, 1, December 12, 1987) and were approved by the Austrian Ministry of Science. All effort was taken to minimize the number of animals used and their suffering.

\section{$r A A V$ vectors}

For rAAV-mediated expression of Cre-GFP, or GFP alone as a control, rAAV serotype 2-based vectors pseudotyped with rAAV serotype 1 capsid proteins (rAAV-2/1) were prepared by a two plasmid cotransfection procedure using HEK293 cells (Grimm et al., 2003). The rAAV-Cre vector was kindly supplied by Dr. Fred H. Gage (University of California, San Diego, La Jolla, CA) (Kaspar et al., 2002). The rAAV vector backbone was flanked by rAAV serotype 2 ITRs and encoded either Cre-GFP or GFP alone under the control of the human cytomegalovirus early enhancer/promoter. The helper plasmid pDP1rs (Grimm et al., 2003) carried the rAAV-2 rep gene and the rAAV-1 cap gene together with essential adenoviral helper functions. Harvest and purification of rAAVs was performed by deoxycholate lysis, iodixanol density gradient centrifugation, and ion-exchange chromatography, as previously described (Zolotukhin et al., 2002). Purified vectors were stored in aliquots at $-80^{\circ} \mathrm{C}$. Physical rAAV titers were determined by quantitative real-time PCR analysis of the recombinant genome. Final titers were $6 \times 10^{10}$ genomic particles (GP) $/ \mathrm{ml}$ and $3 \times 10^{10} \mathrm{GP} / \mathrm{ml}$ for $\mathrm{rAAV} 2 / 1-\mathrm{GFP} / \mathrm{Cre}$ and $\mathrm{rAAV} 2 / 1-\mathrm{GFP}$, respectively.

\section{Stereotaxic microinjection of adeno-associated virus vectors}

Equal numbers of mice from the same litter were injected with either rAAV-Cre $\left(6 \times 10^{7} \mathrm{GP} / \mu \mathrm{l}\right)$ or rAAV-GFP $\left(3 \times 10^{7} \mathrm{GP} / \mu \mathrm{l}\right)$ using a stereotaxic frame (Model 900, David Kopf Instruments) with blunt ear bars. Coordinates according to Paxinos and Franklin (2001) were as follows (in mm, from bregma): BLA: A (rostrocaudal), -1.1 ; L (mediolateral), $\pm 3.2 ; \mathrm{V}$ (dorsoventral), -5.1; CEA: A, $-1.0 ; \mathrm{L}, \pm 2.8 ; \mathrm{V},-4.9$; medial amygdala (MEA): $\mathrm{A},-1.4 ; \mathrm{L}, \pm 2.6 ; \mathrm{V},-5.4$; and bed nucleus of the stria terminalis (BNST): A, $0.0 ; \mathrm{L}, \pm 1.0 ; \mathrm{V},-4.6$. Anesthesia was initiated by injection of ketamine (180 mg/kg, i.p.; Gräub) and maintained throughout the entire procedure by Sevorane inhalation. Injection cannulas prepared from a stainless steel tube (guide cannula gauge 23, injection cannula gauge 30, Coopers Needle Works) were inserted through small holes drilled into the skull on both sides. The cannulas were connected by polyethylene microtubes $(0.28 \times 0.61 \mathrm{~mm}$, NeoLab) to $10 \mu \mathrm{l}$ gastight Hamilton syringes. rAAV vectors were infused bilater- ally using micropumps ( $50 \mathrm{nl} / \mathrm{min}$; Quintessential Stereotaxic Injector, Stoelting). At the end of the infusion, cannulas were kept on site for $5 \mathrm{~min}$ and then slowly withdrawn $(0.5 \mathrm{~mm} / 2 \mathrm{~min})$. After closing the wound, mice were singly housed for optimal recovery.

\section{Behavioral tests}

Behavioral testing was initiated 4 weeks after surgery. All animals were allowed to habituate to the test room for at least $24 \mathrm{~h}$. Tests were conducted between 8:00 A.M. and 12:00 P.M., and repeated at least once with another set of mice. Test settings were validated pharmacologically with wild-type mice responding to anxiolytic or antidepressant drug treatments in the respective tests. Following a suggestion by Crawley and Paylor (1997), tests were performed in the following sequence: elevated plus maze, open field test, and then light/dark test. The tail suspension test was performed in the subsequent week. Intervals between tests were at least $2 \mathrm{~d}$.

Elevated plus maze. This is a widely accepted test for anxiety-like behavior and was performed using a platform $(74 \mathrm{~cm}$ above the floor) with two opposing open arms $(30 \times 5 \mathrm{~cm})$ and two opposing closed arms $(30 \times 5 \times 14 \mathrm{~cm})$, a video camera, and an automatic monitoring unit, as described previously (Lister, 1987; Tschenett et al., 2003). Illumination was 80 lux at the end of the open arms. Mice were placed individually on the center platform $(5 \times 5 \mathrm{~cm})$ facing an open arm. Arm entries were defined when the mouse placed all four paws into that arm. Individual trials lasted $5 \mathrm{~min}$ and were analyzed using a VideoMot2 system (all TSE Systems).

Open field test. The open field test was performed to measure overall motor activity, and was performed as described previously (Hall, 1934; Tschenett et al., 2003; Tasan et al., 2009). The setup consisted of four individual gray plastic boxes $(50 \times 50 \times 30 \mathrm{~cm})$ illuminated with 150 lux at ground level. Boxes were arranged in a square and four mice were tested simultaneously in randomized order. Mice were placed individually into the center of a box. Their behavior was tracked for $10 \mathrm{~min}$ and analyzed using the VideoMot2 system.

Light/dark test. This test was used to evaluate anxiety-like behavior. It was performed as previously described (Crawley and Goodwin, 1980; Tasan et al., 2009), using a plastic box consisting of a dark (1 lux) and a bright (400 lux) compartment that occupied approximately one-third $(16 \times 50 \mathrm{~cm})$ and two-thirds $(34 \times 50 \mathrm{~cm})$ of the testing area, respectively, connected by a central opening $(7 \times 7 \mathrm{~cm})$ at the floor level. Mice were placed individually into the dark compartment not facing the central opening. The behavior of each mouse was tracked for 10 min and analyzed by VideoMot2 system.

Tail suspension test. This test was performed to assess depression-like behavior, as described previously (Steru et al., 1985; Tasan et al., 2009). Using adhesive tape, mice were suspended by their tail to a bar in a box $(28 \times 28 \times 40 \mathrm{~cm})$ open to a camera at the front. The 6 min recording period was divided into $1 \mathrm{~min}$ bins, and the time spent immobile was determined by two independent observers using a stopwatch. Immobility was defined as the absence of limb movement.

Novelty-suppressed feeding. The novelty-suppressed feeding test is a behavioral paradigm that is sensitive to chronic but not acute antidepressant treatment (Bodnoff et al., 1989). The test was performed as described previously (Wang et al., 2008). The testing apparatus consisted of a gray plastic box $(50 \times 50 \times 30 \mathrm{~cm})$ illuminated with 800 lux at ground level. Mice were food deprived for $24 \mathrm{~h}$. On the testing day, a food pellet was placed on a white paper $(15 \mathrm{~cm}$ diameter) and positioned in the center of the arena. Mice were put individually into a corner of the testing arena, and a stopwatch was started immediately. The measure of interest (start of feeding) was scored when the mouse grabbed the pellet and started chewing (maximum time: $5 \mathrm{~min}$ ). Immediately afterward, the mouse was put into the home cage and the amount of food consumed during the subsequent $5 \mathrm{~min}$ period was determined (home-cage food consumption). The loss of weight between food deprivation and testing was determined for each mouse.

\section{Histochemistry}

After the last behavioral test, mice were killed. Brains were either perfused with $4 \%$ paraformaldehyde (PFA) for immunohistochemistry or 
snap frozen (isopentane, $-70^{\circ} \mathrm{C}, 3 \mathrm{~min}$ ) for subsequent in situ hybridization and receptor autoradiography. The position of the needle tract was identified by Nissl staining and GFP autofluorescence.

In situ hybridization. In situ hybridization was performed as described previously in detail (Furtinger et al., 2001). The following customsynthesized (Microsynth, purified by HPLC) oligonucleotides were used as probes: NPY mRNA, 5'-GAG GGT CAG TCC ACA CAG CCC CAT TCG CTT GTT ACC TAG CAT-3'; Y2 mRNA, 5' -GAC AGT CAT TGC TCT GGA CCG CCA TCG TTG CAT TGT CTA CCA CCT GGA GAG C-3' and 5' -CGG AGG CTA CCA ATG TGT AAG GAC ACA GGT GTG AAA GCA CAT GG-3'; Cre-recombinase mRNA, 5'-CCG TCT CTG GTG TAG CTG ATG ATC CGA ATA ACT ACC TGT TTT GCC-3'; GFP mRNA, 5' -CAT GGC CGA CAA GCA GAA GAA CGG CAT CAA GGT GAA CTT CAA GAT-3'; GABA ${ }_{\mathrm{B}}$ receptor mRNA, 5'-GAT GTA TGT GGT CTT CTC TGG TGT GTC TTG TAG CTG CAT GGT GAC TTC TTC C-3'; GABA $_{A}$ receptor $\alpha 2$ subunit mRNA, 5'-CAT CGG GAG CAA CCT GAA CGG AGT CAG AAG CAT TGT AAG TCC-3'. Oligonucleotides $(2.5 \mathrm{pmol})$ were $3^{\prime}$ endlabeled using $\left[{ }^{35} \mathrm{~S}\right] \alpha$-dATP $(50 \mu \mathrm{Ci} ; 1300 \mathrm{Ci} /$ mmol, Hartmann Analytic) and terminal transferase (Roche Diagnostics), as described previously in detail (Furtinger et al., 2001). Hybridization was performed in $50 \%$ formamide, $4 \times$ SSC $(1 \times$ SSC is $150 \mathrm{~mm} \mathrm{NaCl}, 15 \mathrm{~mm}$ sodium citrate, $\mathrm{pH} 7.2), 500 \mu \mathrm{g} / \mathrm{ml}$ salmon sperm DNA, $250 \mu \mathrm{g} / \mathrm{ml}$ yeast tRNA, $1 \times$ Denhardt's solution $(0.02 \%$ Ficoll, $0.02 \%$ polyvinylpyrrolidone, and $0.02 \%$ bovine serum albumin), $10 \%$ dextran sulfate, and $20 \mathrm{~mm}$ dithiothreitol (all from Sigma) at $42^{\circ} \mathrm{C}$ for $18 \mathrm{~h}$. The slides were stringently washed (50\% formamide in $1 \times \mathrm{SSC}, 42^{\circ} \mathrm{C}$ ), and then briefly rinsed in water, followed by $70 \%$ ethanol, and dried. Slides were exposed to BioMax MR films (GE Healthcare) together with $\left[{ }^{14} \mathrm{C}\right]$-microscales for $7-14 \mathrm{~d}$. For evaluation of the hybridization signal at the cellular level, some slides were dipped in Kodak NTB-2 photosensitive emulsion (Kodak; diluted 1:1 with distilled water) at $42^{\circ} \mathrm{C}$, air dried overnight, and then exposed for 4-6 weeks at $4^{\circ} \mathrm{C}$. The BioMax MR films and the dipped slides were developed with Kodak D19 developer. Sections were counterstained with cresyl violet, dehydrated, cleared in butyl acetate, and covered with a coverslip using Eukitt (Merck).

Y2 receptor autoradiography. C-terminally truncated human peptide YY (hPYY $\left.{ }_{3-36}\right)$ was radiolabeled with $\mathrm{Na}^{125} \mathrm{I}(2200 \mathrm{Ci} / \mathrm{mmol}$; PerkinElmer), as described previously (Dumont et al., 1993; Furtinger et al., 2001), and then purified by HPLC using a LiChrospher 100RP-8 reversed-phase column $(5 \mu \mathrm{m}, 250 \times 4 \mathrm{~mm}$, Merck). Peptide was eluted with $0.1 \%$ trifluoroacetic acid and increasing concentrations of acetonitrile (Merck). Receptor autoradiography was performed as described previously in detail (Furtinger et al., 2001). In brief, slides were thawed and then preincubated in freshly prepared modified Krebs-Henseleit buffer (KHB; $118 \mathrm{~mm} \mathrm{NaCl}, 4.8 \mathrm{~mm} \mathrm{KCl,} 1.3 \mathrm{~mm} \mathrm{MgSO}_{4}, 1.2 \mathrm{~mm} \mathrm{CaCl}_{2}, 1.2$ mu $\mathrm{KH}_{2} \mathrm{PO}_{4}, 15 \mathrm{~mm} \mathrm{NaHCO}_{3}, 10 \mathrm{~mm}$ Tris, $50 \mathrm{~mm}$ glucose, $\mathrm{pH} 7.3$ ) at room temperature for $60 \mathrm{~min}$. Sections were incubated in Hellendahl jars containing $50 \mathrm{ml}$ of $\mathrm{KHB}$ supplemented with $0.1 \%$ bovine serum albumin, $0.05 \%$ bacitracin, and $25 \mathrm{pM}\left[{ }^{125} \mathrm{I}\right] \mathrm{hPYY}_{3-36} / 100 \mu \mathrm{l}$ for 120 $\mathrm{min}$ at room temperature. The sections were washed four times for $1 \mathrm{~min}$ in $\mathrm{KHB}$ at $0^{\circ} \mathrm{C}(200 \mathrm{ml})$, dipped five times in $0^{\circ} \mathrm{C}$ deionized water, and then rapidly dried under a stream of cold air. Slides were exposed together
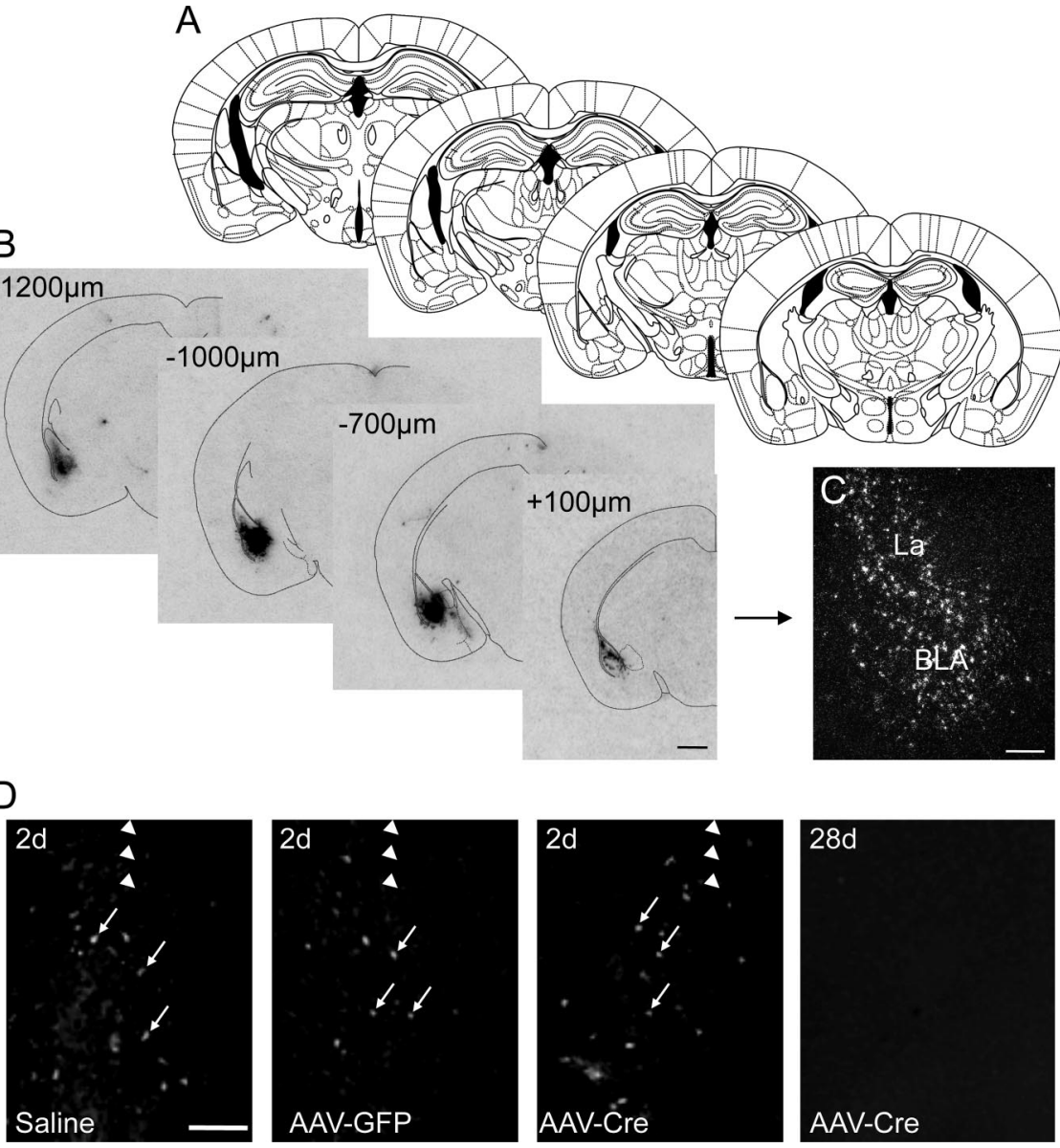

Figure 1. rAAV-Cre-induced expression of Cre mRNA is confined to the BLA. $\boldsymbol{A}$, Schematic drawing from the mouse brain atlas by Paxinos and Franklin (2001) corresponding to sections containing the BLA. B, C, Autoradiographs (B) and a high-magnification

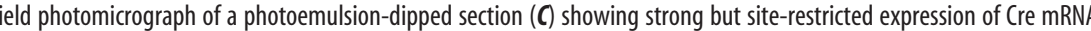
similar for all three conditions after $2 \mathrm{~d}$. No signs of degeneration were seen $28 \mathrm{~d}$ after vector injection. Arrowheads indicate the location of the needle tract. Scale bars: $\boldsymbol{B}, 1 \mathrm{~mm} ; \boldsymbol{C}, \boldsymbol{D}, 500 \mu \mathrm{m}$.

with [ $\left.{ }^{125} \mathrm{I}\right]$-microscales (GE Healthcare) to $\beta$-max Hyperfilm for $10 \mathrm{~d}$. Nonspecific binding was determined in the presence of $1 \mu \mathrm{M}$ NPY.

Quantitative evaluation. Quantitative evaluation of in situ hybridization and receptor autoradiography was done using digitized images of autoradiograms ( 8 bit digitized picture, 256 gray values). Gray values were measured by the public domain program Image $1.38 \times(\mathrm{NIH}$; $255=$ white; $0=$ black) and converted to relative optical density (ROD). ROD values were converted to nanocuries per milligram using standard curves obtained from images of $\left[{ }^{14} \mathrm{C}\right]$-microscales exposed to the same type of film, and then converted to a percentage of control.

Immunohistochemistry. Mice were anesthetized with a lethal dose of thiopental (150 mg/kg, i.p.) and the brains were perfused through the ascending aorta with PBS, pH 7.4 at room temperature ( $2 \mathrm{~min}$ ), followed by ice-cold 4\% PFA (Merck) in PBS for $10 \mathrm{~min}$. Brains were postfixed in $4 \%$ PFA $\left(4^{\circ} \mathrm{C}\right)$ for $90 \mathrm{~min}$, then transferred to $20 \%$ sucrose $\left(4^{\circ} \mathrm{C}\right)$. After incubation for $48 \mathrm{~h}$, tissue was snap frozen in $200 \mathrm{ml}$ of isopentane (2-methylbutane, Merck; $-70^{\circ} \mathrm{C}, 3 \mathrm{~min}$ ). Brains were stored at $-70^{\circ} \mathrm{C}$ until use.

Immunohistochemical analysis was performed on free-floating, PFAfixed, $40-\mu \mathrm{m}$-thick coronal sections using indirect peroxidase labeling, as described previously (Furtinger et al., 2001). The following antisera were used: rabbit anti-NPY antiserum (1:1000) (Bellmann et al., 1991), rabbit anti-GFP antiserum (1:1000, Invitrogen), and rabbit anti-GFAP (1:5000, Dako). Coronal sections were incubated free floating in $10 \%$ normal goat serum (Biomedica) in Tris-HCl-buffered saline (TBS; 50 
A
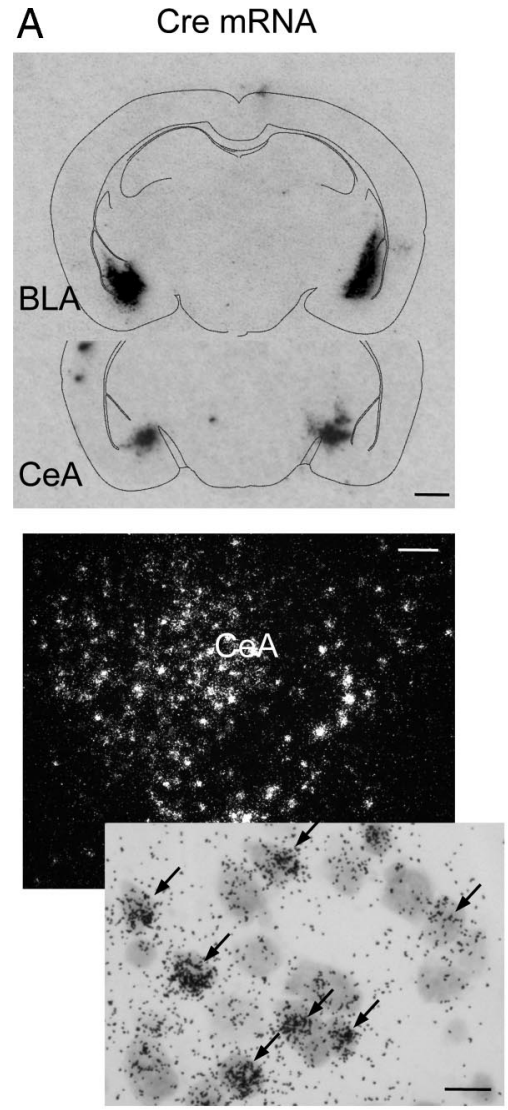

B
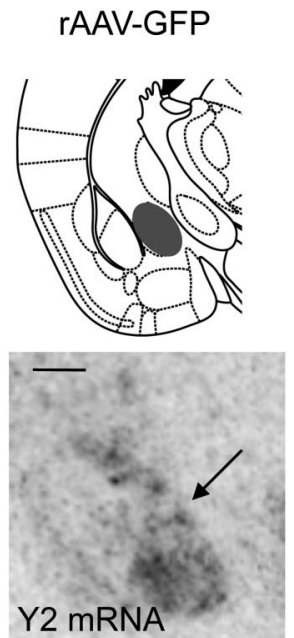

Y2 mRNA
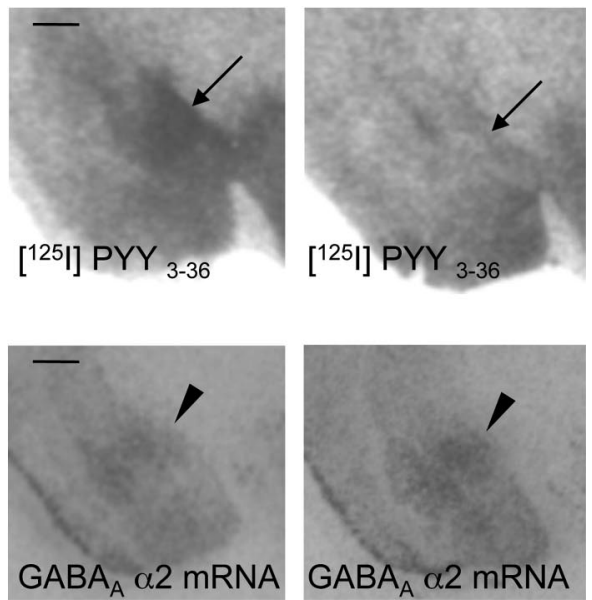

C

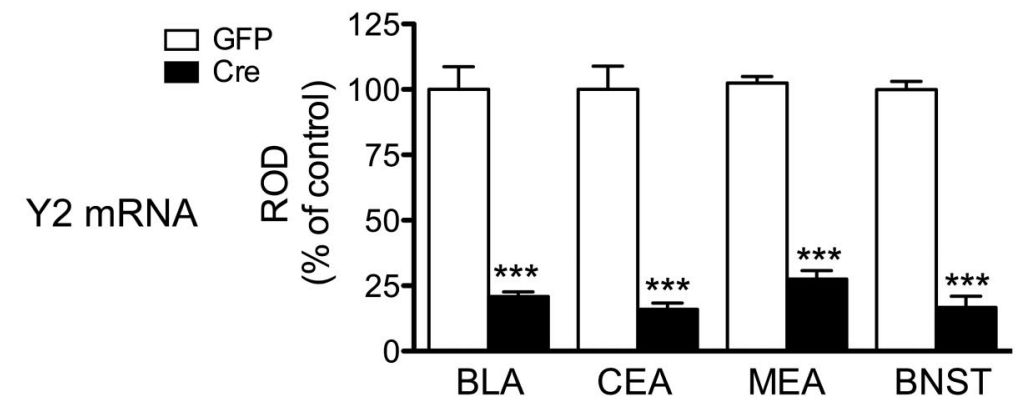

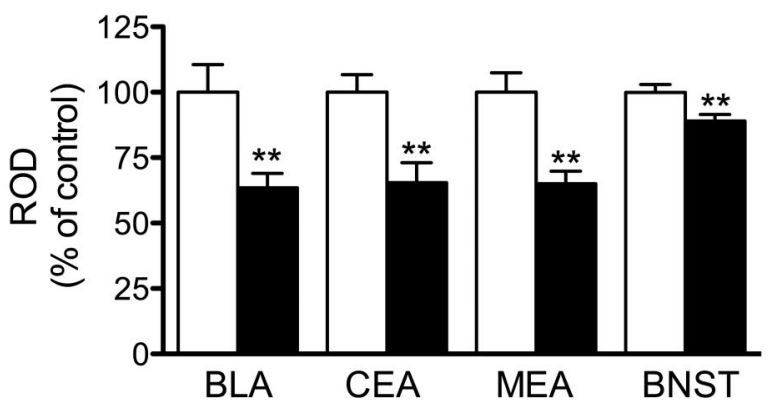

Figure 2. Expression of Cre recombinase in injected areas results in deletion of $\mathrm{Y} 2 \mathrm{mRNA}$ and a profound reduction in $\mathrm{Y} 2$ receptor binding. $A$, In situ hybridization showing expression of (re mRNA in the BLA and CEA. Middle and bottom, Dark-field (middle) and bright-field (bottom) photomicrographs of photoemulsion-dipped sections showing (re-positive cells (arrows) in the CEA. $\boldsymbol{B}$, In situ hybridization showing Cre and Y 2 mRNA expression and Y2 receptor binding in adjacent sections of the CEA in rAAV-Cre- and rAAV-GFP-injected $Y 2^{\text {Iox/lox }}$ mice (arrows mark injections sites). Note the significant reduction in Y2 mRNA levels as compared to the more modest loss of $Y 2$ binding, as quantified in $C$. In contrast to changes in $Y 2$ receptor $m R N A$, there was no change in concentrations of $\mathrm{GABA}_{A} \alpha 2$ subunit mRNA in the CEA 4 weeks after injection of $\mathrm{rAAV}$-Cre into the CEA versus mice injected with rAAV-GFP $\mathrm{mm}, \mathrm{pH}$ 7.2) for $90 \mathrm{~min}$, followed by incubation with primary antiserum (anti-GFP, Invitrogen; $1: 1000$ at $4^{\circ} \mathrm{C}$ for $48-72 \mathrm{~h}$; anti-NPY, $1: 11,000)$. The resulting complex was visualized by incubation with horseradish peroxidase-coupled secondary antibody (1:250 P0448; Dako) at room temperature for 150 $\mathrm{min}$. Sections were incubated in a solution of $0.03 \% 3,3^{\prime}$-diaminobenzidine tetrahydrochloride (Sigma) and $0.005 \% \mathrm{H}_{2} \mathrm{O}_{2}$ in TBS for 6 min. Sections were then mounted on slides, air dried, dehydrated, and then covered with a coverslip. After each incubation step (with the exception of preincubation with $10 \%$ normal goat serum), sections were washed three times for 5 min each with TBS. All buffers and antibody dilutions, except the buffer used for washing after peroxidase treatment and the diaminobenzidine reaction buffer, contained $0.4 \%$ Triton X-100. Normal goat serum (10\%) was included in all buffers containing antibodies. In each experiment, sections without primary antibody were included as a control. No immunopositive elements were detected in control sections.

Histopathology. Histopathological validation was done on six mouse brains removed 2 and $28 \mathrm{~d}$ after rAAV-GFP/Cre injection into the BLA. The glial marker glial fibrillary acidic protein (GFAP) was analyzed by immunohistochemistry. Degenerating neurons were labeled with Fluoro-Jade C (Histo-Chem) in PFA-fixed, slide-mounted $30 \mu \mathrm{m}$ coronal brain sections, as described previously in detail (Schmued et al., 2005).

\section{Statistical analysis}

Data are presented as means \pm SEM. Data were analyzed for normal distribution and equal variances using GraphPad Prism software (Prism 5 for Macintosh, GraphPad Software). Statistical analysis of behavior was done by Student's $t$ test for data with normal distribution or Mann-Whitney test as a nonparametric test. Two-tailed Student's $t$ test was used for evaluating changes in Y2 mRNA and receptor binding. For analyzing the effect of rAAV-Cre injection into the CEA on Y2 receptor density in CEA projection areas, a one-way ANOVA with Bonferroni post hoc test was used.

\section{Results}

\section{Vector localization and extent of transgene expression}

To optimize the conditions for injection and expression of Cre-GFP, we injected different volumes $(0.2,0.5$, and $1.0 \mu \mathrm{l})$ of rAAV-Cre bilaterally into the BLA of $Y 2^{l o x / l o x}$ mice. A volume of $1.0 \mu$ l exhibited optimal site-restricted penetration of the

(arrow heads), excluding an unspecific effect of $\mathrm{Cre}(\boldsymbol{B})$. Scale bars: $\boldsymbol{A}, 1 \mathrm{~mm}$ (film autoradiography), $50 \mu \mathrm{m}$ (dark field), $10 \mu \mathrm{m}$ (bright field); $\boldsymbol{B}, 500 \mu \mathrm{m}$. $\boldsymbol{C},{ }^{* *} p<0.01$, ${ }^{* * *} p<0.001$ as compared to all the respective controls (Student's $t$ test). 
vector. Cre mRNA expression was restricted to an area $\sim 1.5 \mathrm{~mm}$ rostrocaudally and $1.0 \mathrm{~mm}$ dorsoventrally and mediolaterally (Fig. 1A). The shape of the area of Cre expression was not strictly spherical, but resembled the laminar structure of the target area. Thus, the medial and lateral parts of the external capsule limited vector diffusion. Expression of Cre mRNA appeared to be restricted to neurons, based on an analysis of photoemulsion-dipped sections (Fig. 1C). We performed a time course analysis, and found that Cre mRNA and GFP immunoreactivity were already detectable $24 \mathrm{~h}$ and $2 \mathrm{~d}$ after injection, respectively, and there was a significant reduction of $\mathrm{Y} 2 \mathrm{mRNA}$ levels $7 \mathrm{~d}$ after injection. Maximal inhibition of Y2 receptor binding, however, lasted 3-4 weeks. Thus, behavioral tests were performed after 4 weeks.

To investigate possible nonspecific neuropathological effects of vector injection, we performed Nissl staining, Fluoro-Jade C labeling, and immunocytochemical analysis of GFAP to assess neuronal degeneration and astrocyte proliferation, respectively. Two and twenty-eight days after injection with rAAV-Cre or rAAV-GFP, we observed minimal neuronal damage (Fig. $1 D$ ) and a slight increase in the number of GFAPimmunoreactive astrocytes along the needle tract (data not shown). The increase in GFAP-positive astrocytes was considerably less at the injection site, and did not differ from saline-injected mice (data not shown).

\section{Localized decreases in $\mathrm{Y} 2$ receptor} mRNA and protein following injection of rAAV-Cre

Vector preparations were injected into the CEA, BLA, MEA, or BNST of $Y 2^{\text {lox/lox }}$

mice, all of which are intimately involved in emotional processing (McDonald, 2003). Littermates were injected with either rAAV-Cre or rAAV-GFP, and behavioral tests were performed 4 weeks after injection. After behavioral testing, mice were killed, and the site and extent of Cre and GFP expression was verified (Fig. 2A), as well as the inhibition of Y2 receptor mRNA expression and Y2 receptor binding (Fig. $2 B$ ). Only mice with strong, localized bilateral transgene expression were included in the analysis of the results of the behavioral testing.

As shown in Figure 2, there was a marked reduction of Y2 mRNA expression at all sites of injection as compared to rAAVGFP-injected littermates (BLA, $79.1 \pm 1.83 \%$ reduction, $p<$ 0.0001 ; CEA, $84.0 \pm 2.33 \%$ reduction, $p<0.0001$; MEA, $72.4 \pm$ $3.15 \%$ reduction, $p<0.0001$; BNST, $83.2 \pm 4.26 \%$, reduction, $p<0.0001$ ) (Fig. 2C). The specificity of gene deletion was confirmed by unaltered expression of mRNAs for the $\mathrm{GABA}_{\mathrm{B}}$ receptor $(111.2 \pm 9.37 \%$ of control, $p=0.43)$ and the $\alpha 2$ subunit of the $\mathrm{GABA}_{\mathrm{A}}$ receptor $(95.8 \pm 4.98 \%$ of control, $p=0.62)$ at the

\section{Anxiety-related behavior}

Elevated plus maze

Light/ dark test
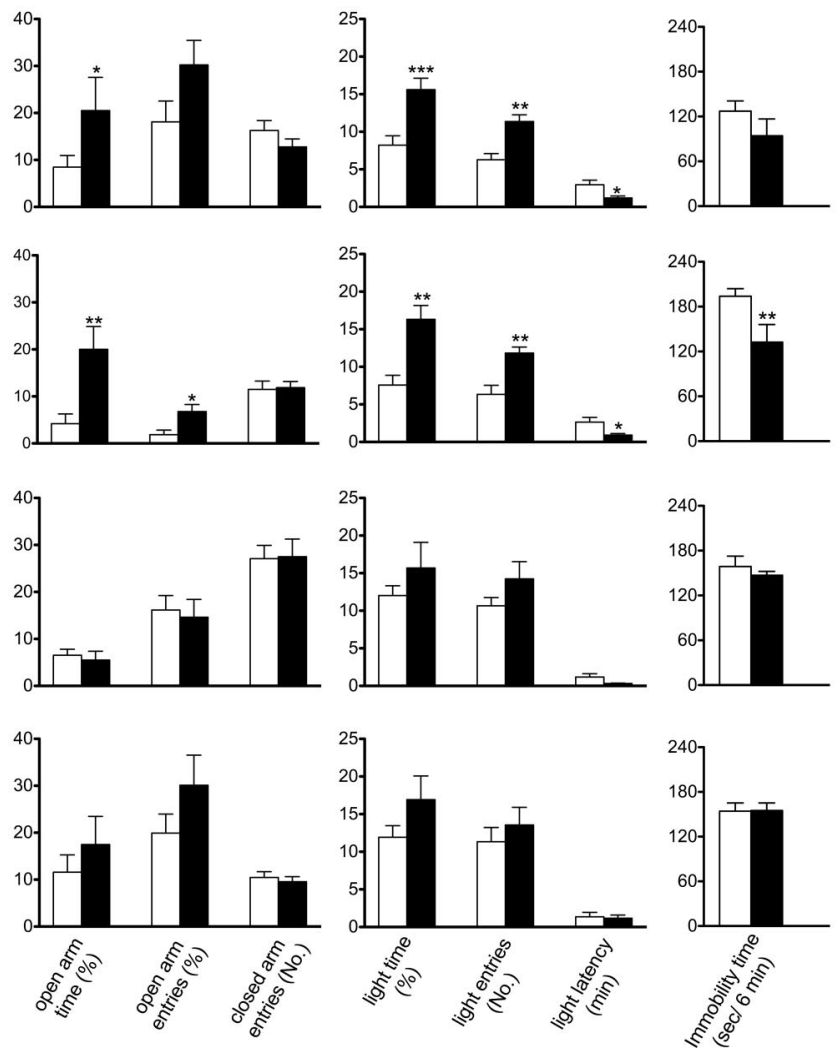

Figure 3. Anxiety- and depression-like behavior after site-specific deletion of $Y 2$ receptors in $Y 2^{\text {lox/lox }}$ mice. The time spent in int trend after $\mathrm{rAAV}$-Cre injection into the BLA Similarly, the light/dark test revealed an anxiolytic effect of $Y 2$ receptor gene deletion in the CEA and BLA, as indicated by a significant increase in the time spent in the light box and number of entries, and a decreased latency to enter the light compartment. The tail suspension test revealed an antidepressant effect (reduced time bite indicated that overall motor activity was not affected. Numbers of animals with validated bilateral site-restricted Cre mRNA or GFP mRNA expression were as follows (rAAV-Cre/rAAV-GFP): BLA, 10/15; CEA, 6/7; MEA, 8/12; BNST, 8/11. * ${ }^{*} p<0.05$, ${ }^{* *} p<0.01,{ }^{* * *} p<0.001$ as compared to the respective controls (Student's $t$ test).

injection site (Fig. 2 B). Y2 receptor density, as measured by binding of the Y2-selective ligand $\left[{ }^{125} \mathrm{I}\right] \mathrm{PYY}_{3-36}$, was also significantly reduced in all injected brain areas, although to a lesser extent than Y2 mRNA expression (BLA, $36.5 \pm 5.52 \%$ reduction, $p=0.0036$; CEA, $34.5 \pm 7.63 \%$ reduction, $p=0.0024$; MEA, $34.9 \pm 4.77 \%$ reduction, $p=0.0017$; BNST, $10.9 \pm 2.43 \%$ reduction, $p=$ 0.009 ) (Fig. 2C). Deletion of the Y2 gene in the CEA resulted in the concomitant loss of $\mathrm{Y} 2$ binding within the CEA $(37.8 \pm 5.43)$ and a reduction in the number of $\mathrm{Y} 2$ binding sites in the stria terminalis/BNST $(36.2 \pm 3.73)$, which indicated that $\mathrm{Y} 2$ receptors are located on fibers that arise from the CEA. PYY $\mathrm{PY}_{36}$ at a concentration of $25 \mathrm{pm}$ is a highly selective ligand for Y2 receptors with considerably lower affinity for Y5 receptors. To exclude a lack of selectivity of the ligand for Y2 receptors, we concomitantly investigated binding in germ-line Y2 receptor KO mice. $\left[{ }^{125} \mathrm{I}\right] \mathrm{PYY}_{3-36}$ binding was reduced to almost background level in $\mathrm{Y} 2 \mathrm{KO}$ mice (e.g., CEA: $95.98 \pm 2.79 \%$ reduction, $p<0.0001)$. 
Table 1. Changes in Y2 receptor binding in presumed target areas of efferent projections of the CEA after Y2 gene deletion in the CEA

\begin{tabular}{lc}
\hline Brain area & \% of control \pm SEM \\
\hline Ncl. accumbens, core & $80.4 \pm 5.00$ \\
$\mathrm{Ncl}$. accumbens, shell & $64.0 \pm 4.96^{*}$ \\
Lateral septum & $87.0 \pm 6.31$ \\
Stria terminalis/bed nucleus of stria terminalis & $81.2 \pm 3.01^{*}$ \\
Central amygdala & $62.5 \pm 4.16^{* * *}$ \\
Lateral hypothalamus & $102.4 \pm 3.88$ \\
Ventral hippocampus (CA1) & $95.8 \pm 3.80$ \\
Periaqueductal gray & $96.6 \pm 5.21$ \\
Locus ceruleus & $75.2 \pm 3.04^{*}$
\end{tabular}

[125] $]$ hPYY ${ }_{3-36}$ was determined 4 weeks after rAAV-Cre injection $(n=16)$ into the CEA and compared with rAAV-GFP-injected mice $(n=10)$. Stringent statistical testing by ANOVA and Bonferroni post hoc test was used. ${ }^{*} p<0.05,{ }^{* * *} p<0.001$
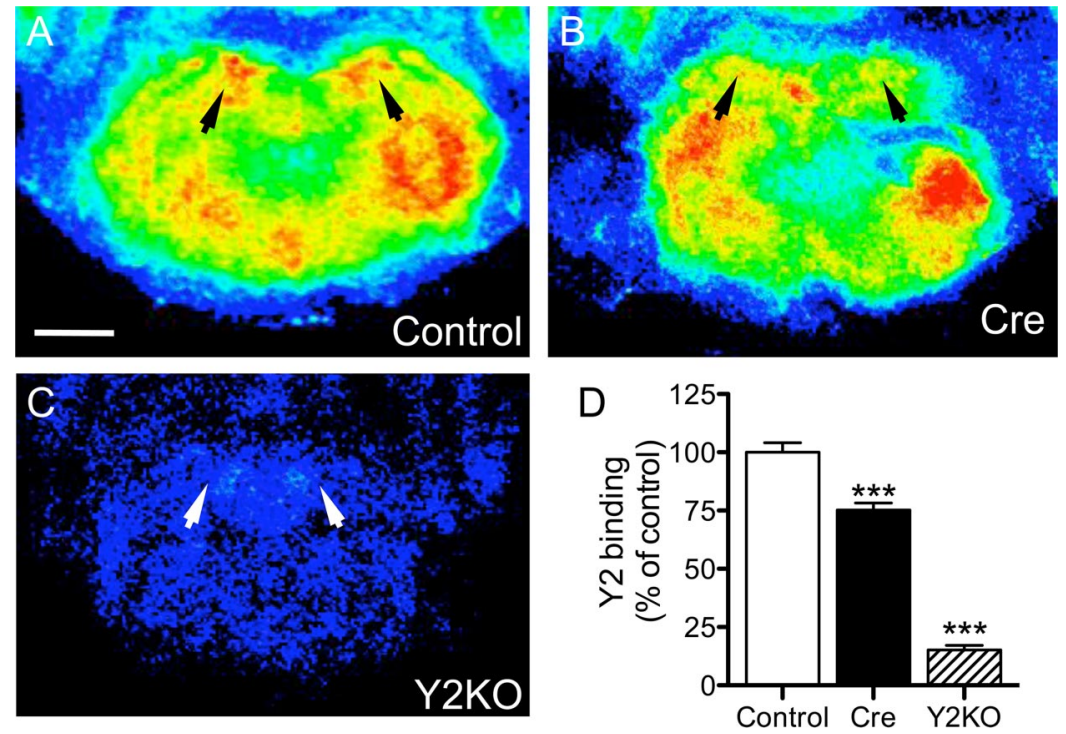

Figure 4. $\quad Y 2$ receptor binding is reduced in the locus ceruleus after $Y 2$ gene deletion in the CEA. $\boldsymbol{A}-\boldsymbol{C}$, Pseudocolor-coded images of $\left[{ }^{125} \mathrm{I}\right] \mathrm{hPYY}{ }_{3-36}$ receptor autoradiographs of representative brain sections of conditional Y2 K0 mice 4 weeks after rAAV-GFP $(\boldsymbol{A})$ and $\mathrm{rAAV}$-Cre $(\boldsymbol{B})$ injections, respectively, and of a germ-line Y2 $\mathrm{KO}$ mouse $(\boldsymbol{C})$, are shown. $\left[{ }^{125} \mathrm{I}\right] \mathrm{hPYY}{ }_{3-36}$ was almost abolished in germ-line $\mathrm{Y} 2 \mathrm{KO}$ mice, indicating the specificity of the ligand for $\mathrm{Y} 2$ receptors. Arrowheads denote the location of the locus ceruleus Scale bar, $1 \mathrm{~mm}$. In $\boldsymbol{D}$, a quantitative evaluation of [ $\left.{ }^{125} \mathrm{I}\right] \mathrm{hPYY}{ }_{3-36}$ binding in the locus ceruleus is shown $(n=16) .{ }^{* * *} p<0.001$, one-way ANOVA, with Bonferroni post hoc test.

\section{Y2 receptor deletion does not affect motor activity}

The motor activity of injected mice was assessed using the open field test. Motor activity was not significantly different in mice injected with rAAV-Cre or rAAV-GFP at any site examined. The total distance that rAAV-Cre-injected mice traveled in $10 \mathrm{~min}$ was similar to that of rAAV-GFP-injected mice. After rAAV-Cre injection, the percentage difference in distance traveled as compared to rAAV-GFP mice was as follows: BLA, $108.7 \pm 10.20 \%$, $p=0.54$; CEA, $99.6 \pm 8.00 \%, p=0.96$; MEA, $112.2 \pm 8.37 \%, p=$ 0.24 ; BNST, $106.4 \pm 6.02 \%, p=0.50$. Elevated plus maze motor activity was not affected by injection of rAAV-Cre, as there was no significant change in closed arm entries following injection (BLA, $p=0.68$; CEA, $p=0.86$; MEA, $p=0.41$; and BNST, $p=$ 0.62 ) (Fig. 3).

Effect of Y2 receptor gene deletion on anxiety-like behavior To assess anxiety-like behavior, we used the elevated plus maze and the light/dark test. As shown in Figure 3, according to both tests, anxiety-like behavior was reduced by $\mathrm{Y} 2$ receptor gene de- letion in the BLA and CEA, but not the MEA and BNST. In the elevated plus maze, open arm times and open arm entries increased ( $p=0.048$ ) following Y2 receptor gene deletion in the BLA. Receptor deletion in the CEA also resulted in an increase in open arm times and open arm entries $(p=0.0065$ and $p=0.015$, respectively), which was indicative of reduced anxiety in these mice. There were no significant changes in open arm times and open arm entries after rAAV-Cre injection into the MEA ( $p=$ 0.64 and $p=0.75$, respectively) or the BNST $(p=0.38$ and $p=$ 0.17 , respectively). There was clearly a less anxious phenotype in the light/dark test after receptor deletion in the BLA or CEA (Fig. 3 ), as indicated by significantly increased times spent in the light compartment ( $p=0.0009$ and $p=0.0016$, respectively), but not the MEA or BNST ( $p=0.26$ and $p=0.13$, respectively). Similarly, the number of entries into the lighted area was significantly increased following rAAV-Cre injection into the BLA $(p=0.0012)$ or CEA $(p=$ $0.0123)$, but not the MEA $(p=0.13)$ or BNST ( $p=0.47)$. Accordingly, latency to first entry into the lighted area was reduced after receptor deletion in the BLA $(p=0.0182)$ and CEA $(p=$ $0.046)$, but not the MEA ( $p=0.18$ ) or $\operatorname{BNST}(p=0.82)$.

\section{Effect of Y2 receptor gene deletion on} depression-like behavior

To assess depression-like behavior, we examined the stress-coping ability of mice using the tail suspension test. As shown in Figure 3, Y2 gene deletion in the CEA resulted in a significant reduction in time spent immobile (by $31 \%$ as compared to controls, $p=0.01$ ), which indicated reduced depression-like behavior, but injection into the BLA $(p=0.68)$, $\operatorname{MEA}(p=0.47)$, or BNST $(p=0.96)$ had no effect. Furthermore, the reduction in depression-like behavior after deletion of the Y2 gene in the CEA was confirmed in the novelty-suppressed feeding test. The latency to feed was significantly reduced $(p=0.04)$ after injection of rAAV-Cre into the CEA (mean \pm SEM; $166.0 \pm$ 28.65 s) compared with rAAV-GFP-injected mice (252.0 \pm $24.11 \mathrm{~s})$.

\section{Evaluation of Y2 receptor binding in terminal areas of} the amygdala

The predominantly presynaptic Y2 receptors may not only be present on local amygdala neurons, but also on axon terminals of projection neurons arising from the CEA. To investigate this, we determined by receptor autoradiography the Y2 receptor density in projection areas of the CEA after injection of rAAV-Cre into the CEA. In addition to the reduction of Y2 receptor binding in the central amygdala, we observed a significant reduction of Y2 receptor binding in the stria terminalis/BNST, the nucleus accumbens shell, and the locus ceruleus (Table 1, Fig. 4). In the nucleus accumbens core ( $\mathrm{ncl}$.) and the lateral septal nucleus, there was a tendency for a reduction in Y2 sites, whereas they were unchanged in the hippocampus and the lateral hypothalamus (Table 1). 

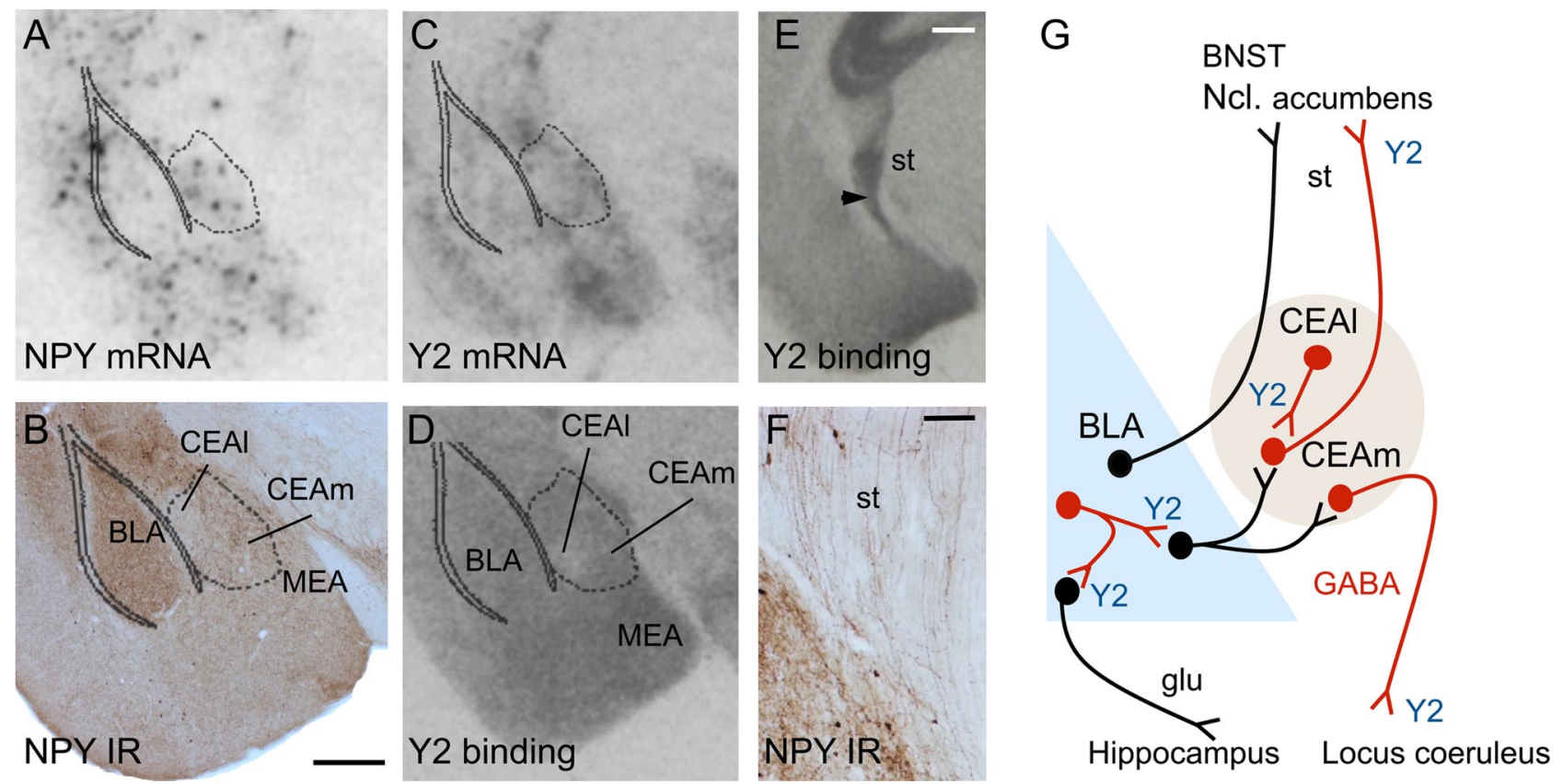

Hippocampus

Locus coeruleus

Figure 5. $A-F$, Anatomical distribution of NPY and $Y 2$ receptors and $m$ RNA in the BLA and CEA. NPY and Y2 $m R N A$ and protein were widely distributed within different amygdaloid nuclei. A dense NPY- $(\boldsymbol{E})$ and Y2-receptor- $(\boldsymbol{F})$ containing fiber tract arising from the CEA contributes to the stria terminalis (st). In $\boldsymbol{G}$, a schematic drawing of the proposed Y2-containing projections is shown. Proposed sites of anxiolytic action of the Y2 deletion are the terminals of GABA/NPY interneurons in the BLA and the CEA, which project from the lateral part of the CEA (CEAI) to its medial extension (CEAm). Importantly, deletion of the Y2 receptor gene in the CEA causes deletion of Y2 receptors in the terminals of its projections, e.g., in the ncl. accumbens, stria terminalis/BNST, and locus ceruleus, where subsequent anxiolytic/antidepressant effects might be integrated. Glutamatergic projections are shown in black, GABAergic in red. Scale bars: $\boldsymbol{B}$ (for $\boldsymbol{A}-\boldsymbol{D}), \boldsymbol{E}, 500 \mu \mathrm{m} ; \boldsymbol{F}, 100 \mu \mathrm{m}$.

\section{Correlation of $\mathrm{Y} 2$ receptor density in the CEA and stria} terminalis/BNST with anxiety- and depression-like behavior To investigate a possible contribution of Y2 receptor deletion in the CEA and in its target areas on the anxiolytic and antidepressant effects after Y2 gene deletion in the CEA, we correlated the reduction of $\mathrm{Y} 2$ receptors in the CEA and in the stria terminalis/ BNST with the percentage of open arm time in the elevated plus maze and with the immobility time in the tail suspension test, respectively. There was a significant correlation of the reduction of $\mathrm{Y} 2$ receptor sites in the CEA $\left(r^{2}=0.53, p=0.003\right)$ and stria terminalis/BNST $\left(r^{2}=0.31, p=0.04\right)$ with the percentage of open arm time in the elevated plus maze. The immobility time in the tail suspension test significantly correlated with the reduction in Y2 binding in the stria terminalis/BNST $\left(r^{2}=0.25, p=0.03\right)$ but not in the CEA $\left(r^{2}=0.11, p=0.15\right)$.

\section{Distribution of NPY and Y2 receptors in the amygdala}

In agreement with previous reports, NPY immunoreactivity and mRNA expression were widely distributed within amygdaloid nuclei, most notably in the BLA and CEA (Fig. 5). Expression of NPY and Y2 receptors appeared to be slightly higher in the medial extension than in the lateral extension of the CEA (Fig. 5A-D). Similarly, Y2 receptor binding and Y2 mRNA expression were detected throughout amygdaloid nuclei. $Y 2$ receptor binding was particularly dense in the stria terminalis (Fig. $5 E$ ), which also contained dense NPY-positive fibers (Fig. $5 F$ ).

\section{Discussion}

The results of the current study pinpoint specific nuclei of the amygdala complex (CEA and BLA) as crucial sites of NPY/Y2 receptor-mediated integration of anxiety and depression, supporting and extending the evidence for a substantial role of NPY in anxiety and depression. The use of stereotactic microinjection of rAAV-Cre into the brains of conditional Y2 knock-out mice allowed the site-selective introduction of a selective deletion of the NPY-Y2 receptor gene in adult animals. This procedure was minimally invasive, long-lasting, and circumvented possible adaptive mechanisms that could arise during embryonic or postnatal development (Holmes, 2001). The loss in Y2 receptor binding was consistently less pronounced than the reduction in $\mathrm{Y} 2$ receptor mRNA levels in the injected brain area, which indicates that Y2 receptors located presynaptically on afferent nerve terminals were spared (Colmers et al., 1991).

Y2 receptor mRNA is expressed at high levels in the CEA and MEA, and to a lesser extent in the BLA (Fig. 5). However, the cell types that express Y2 receptors in the different amygdaloid nuclei are not precisely known. NPY-immunoreactive fibers are abundant throughout the amygdala (Gustafson et al., 1986), and colocalize with Y2 receptors (Colmers et al., 1991; Chen and van den Pol, 1996; Caberlotto et al., 2000; Kash and Winder, 2006; Stanić et al., 2006). Deletion of Y2 receptors may therefore result in a loss of presynaptic inhibition of GABA and NPY release from a subpopulation of GABA neurons that also contain NPY and Y2 receptors (McDonald, 1989; McDonald and Pearson, 1989). The resulting increase in NPY and GABA release may lead to augmented stimulation of postsynaptic $\mathrm{Y} 1$ and $\mathrm{GABA}_{\mathrm{A}}$ receptors, both of which are associated with reduced anxiety (Heilig et al., 1993; Heilig, 1995; Karlsson et al., 2008). In the CEA or BLA, these changes may take place at the level of local circuitry neurons. Interneurons that coexpress GABA and NPY are present in the BLA and the CEA (McDonald, 1989; McDonald and Pearson, 1989). In the CEA, they are located primarily in the lateral part, and from there connect to the medial CEA (see schematic in Fig. $5 G$ ). Deletion of Y2 receptors in these neurons may cause increased GABA/NPY-ergic transmission (by alleviating the inhibition of transmitter release), and subsequent anxiolytic effects. In contrast, local injection of the Y2 agonist $\mathrm{NPY}_{13-36}$ into the 
BLA is anxiogenic (Sajdyk et al., 2002), which implicates BLA local circuitry neurons as having a causative role.

The anxiolytic effect of Y2 gene deletion in the CEA not only correlated with the reduction of Y2 binding sites in the CEA but also in the stria terminalis/BNST. This strongly indicates a role of GABAergic projection neurons arising from the CEA in the integration of anxiety-related behavior. Histochemical analysis has demonstrated that there are high concentrations of GABA and NPY in axon bundles, particularly those arising from the medial extension of the CEA (Dong et al., 2001) (Fig. 5E,F). These projections transmit anxiety-related information from the amygdala to vegetative centers in the brainstem, such as the ncl. tractus solitarius, the locus ceruleus, the periaqueductal gray matter, and the ncl. parabrachialis, and connect through the stria terminalis to the BNST, the ncl. accumbens shell, and the lateral septum (LeDoux et al., 1988; Dong et al., 2001). Our present experiments demonstrate that fiber tracts arising from the CEA and terminating in the stria terminalis/BNST, the ncl. accumbens shell representing the central part of the extended amygdala (Alheid, 2003), or the locus ceruleus carry also Y2 receptors. In particular the BNST might contribute substantially to the integration of anxiety by amygdaloid nuclei, including Y2-mediated modulation (Sajdyk et al., 2008). rAAV-Cre injection into the BNST, however, had no anxiolytic effect (Fig. 3) and resulted in a minute reduction of $\mathrm{Y} 2$ receptors (Fig. $2 C$ ), indicating that $\mathrm{Y} 2$ receptors located on terminals arising from other areas, e.g., the CEA, may integrate the Y2-mediated functions (Dong et al., 2001). This is supported by the correlation of the reduction of Y2 binding after rAAV-Cre injection into the CEA with the behavioral outcome in the anxiety tests. Afferent GABA- and NPY-containing terminals in the BNST, as well as the ncl. accumbens and the locus ceruleus, are therefore candidate sites for the integration of Y2-mediated anxiogenic effects. Using whole-cell recordings in slice preparations, Kash and Winder (2006) demonstrated the Y2-mediated presynaptic inhibition of GABA release in the BNST, whereas CRF (corticotropin-releasing factor) increased GABAergic transmission at the same site by a postsynaptic mechanism.

Interestingly, deletion of Y2 receptors in the MEA had no effect on anxiety- and depression-like behavior, despite the fact that the MEA is rich in Y2 receptors (Fig. $5 C, E$ ). In fact, there is evidence that the MEA plays an important role in emotional stress-related behavior (Ebner et al., 2004). It is part of the main olfactory and accessory olfactory circuits (Swanson and Petrovich, 1998), and thus may be important in social recognition and aggression-like behaviors. These behavioral aspects, however, were not detected by our tests.

Another interesting result of the current study was the identification of divergent sites in which Y2 receptor gene deletion resulted in anxiolytic and antidepressant effects. The antidepressant effect of Y2 receptor gene deletion, which was first demonstrated in germ-line Y2 KO mice (Redrobe et al., 2003; Tschenett et al., 2003), localized to the CEA, but did not involve Y2 receptors in the BLA or any other brain areas examined. Thus, the brain sites and mechanisms responsible for the Y2-mediated effects on depression may be different from those that integrate anxiety. Since the antidepressant effect of Y2 gene deletion in the CEA, however, correlated with the reduction in Y2 binding sites in the stria terminalis/BNST, it is likely integrated in target areas of the CEA. In addition, Y2 gene deletion in Y2/GABA-containing projections from the CEA to the locus ceruleus may influence firing of noradrenergic neurons and thus depression/ stress coping-related behavior (Harro and Oreland, 2001). No such output connection is known for the BLA.
In summary, we identified the CEA and BLA as crucial sites for NPY-Y2 receptor-mediated anxiety-related behavior in mice. In particular, the CEA was critical in this context. Our results suggest that site-specific deletion of the $\mathrm{Y} 2$ receptor gene in the CEA might not only have a local effect, but also a distal effect, and thus might influence emotion-driven behavior simultaneously at successive brain sites. This in turn might lead to an integrated anxiolytic/antidepressive reaction that is adjusted to the requirements of a given emotional challenge. Novel therapies that target the NPY Y2 receptor may therefore prove to be successful in treating affective disorders in a graded and demand-oriented way.

\section{References}

Alheid GF (2003) Extended amygdala and basal forebrain. Ann N Y Acad Sci 985:185-205.

Bacchi F, Mathé AA, Jiménez P, Stasi L, Arban R, Gerrard P, Caberlotto L (2006) Anxiolytic-like effect of the selective neuropeptide Y Y2 receptor antagonist BIIE0246 in the elevated plus-maze. Peptides 27:3202-3207.

Bannon AW, Seda J, Carmouche M, Francis JM, Norman MH, Karbon B, McCaleb ML (2000) Behavioral characterization of neuropeptide $Y$ knockout mice. Brain Res 868:79-87.

Bellmann R, Widmann R, Olenik C, Meyer DK, Maas D, Marksteiner J, Sperk G (1991) Enhanced rate of expression and biosynthesis of neuropeptide Y after kainic acid-induced seizures. J Neurochem 56:525-530.

Bodnoff SR, Suranyi-Cadotte B, Quirion R, Meaney MJ (1989) A comparison of the effects of diazepam versus several typical and atypical antidepressant drugs in an animal model of anxiety. Psychopharmacology (Berl) 97:277-279.

Broqua P, Wettstein JG, Rocher MN, Gauthier-Martin B, Junien JL (1995) Behavioral effects of neuropeptide $Y$ receptor agonists in the elevated plus-maze and fear-potentiated startle procedures. Behav Pharmacol 6:215-222.

Caberlotto L, Fuxe K, Hurd YL (2000) Characterization of NPY mRNAexpressing cells in the human brain: co-localization with Y2 but not Y1 mRNA in the cerebral cortex, hippocampus, amygdala, and striatum. J Chem Neuroanat 20:327-337.

Chen G, van den Pol AN (1996) Multiple NPY receptors coexist in pre- and postsynaptic sites: inhibition of GABA release in isolated self-innervating SCN neurons. J Neurosci 16:7711-7724.

Colmers WF, Klapstein GJ, Fournier A, St-Pierre S, Treherne KA (1991) Presynaptic inhibition by neuropeptide $\mathrm{Y}$ in rat hippocampal slice in vitro is mediated by a Y2 receptor. Br J Pharmacol 102:41-44.

Crawley J, Goodwin FK (1980) Preliminary report of a simple animal behavior model for the anxiolytic effects of benzodiazepines. Pharmacol Biochem Behav 13:167-170.

Crawley JN, Paylor R (1997) A proposed test battery and constellations of specific behavioral paradigms to investigate the behavioral phenotypes of transgenic and knockout mice. Horm Behav 31:197-211.

Dong HW, Petrovich GD, Swanson LW (2001) Topography of projections from amygdala to bed nuclei of the stria terminalis. Brain Res Brain Res Rev 38:192-246.

Dumont Y, Fournier A, St-Pierre S, Quirion R (1993) Comparative characterization and autoradiographic distribution of neuropeptide $\mathrm{Y}$ receptor subtypes in the rat brain. J Neurosci 13:73-86.

Ebner K, Rupniak NM, Saria A, Singewald N (2004) Substance P in the medial amygdala: emotional stress-sensitive release and modulation of anxiety-related behavior in rats. Proc Natl Acad Sci US A 101: $4280-4285$.

Furtinger S, Pirker S, Czech T, Baumgartner C, Ransmayr G, Sperk G (2001) Plasticity of Y1 and Y2 receptors and neuropeptide $\mathrm{Y}$ fibers in patients with temporal lobe epilepsy. J Neurosci 21:5804-5812.

Grimm D, Kay MA, Kleinschmidt JA (2003) Helper virus-free, optically controllable, and two-plasmid-based production of adeno-associated virus vectors of serotypes 1 to 6 . Mol Ther 7:839-850.

Gustafson EL, Card JP, Moore RY (1986) Neuropeptide Y localization in the rat amygdaloid complex. J Comp Neurol 251:349-362.

Hall CS (1934) Emotional behavior in the rat: I. Defecation and urination as measures of individual differences in emotionality. J Comp Psychol 1:385-403.

Harro J, Oreland L (2001) Depression as a spreading adjustment disorder of 
monoaminergic neurons: a case for primary implication of the locus coeruleus. Brain Res Brain Res Rev 38:79-128.

Heilig M (1995) Antisense inhibition of neuropeptide Y (NPY)-Y1 receptor expression blocks the anxiolytic-like action of NPY in amygdala and paradoxically increases feeding. Regul Pept 59:201-205.

Heilig M, McLeod S, Brot M, Heinrichs SC, Menzaghi F, Koob GF, Britton KT (1993) Anxiolytic-like action of neuropeptide Y: mediation by Y1 receptors in amygdala, and dissociation from food intake effects. Neuropsychopharmacology 8:357-363.

Holmes A (2001) Targeted gene mutation approaches to the study of anxiety-like behavior in mice. Neurosci Biobehav Rev 25:261-273.

Karlsson RM, Choe JS, Cameron HA, Thorsell A, Crawley JN, Holmes A, Heilig M (2008) The neuropeptide Y Y1 receptor subtype is necessary for the anxiolytic-like effects of neuropeptide $\mathrm{Y}$, but not the antidepressant-like effects of fluoxetine, in mice. Psychopharmacology (Berl) 195:547-557.

Kash TL, Winder DG (2006) Neuropeptide Y and corticotropin-releasing factor bi-directionally modulate inhibitory synaptic transmission in the bed nucleus of the stria terminalis. Neuropharmacology 51:1013-1022.

Kaspar BK, Vissel B, Bengoechea T, Crone S, Randolph-Moore L, Muller R, Brandon EP, Schaffer D, Verma IM, Lee KF, Heinemann SF, Gage FH (2002) Adeno-associated virus effectively mediates conditional gene modification in the brain. Proc Natl Acad Sci U S A 99:2320-2325.

Kessler RC, Berglund P, Demler O, Jin R, Merikangas KR, Walters EE (2005) Lifetime prevalence and age-of-onset distributions of DSM-IV disorders in the National Comorbidity Survey Replication. Arch Gen Psychiatry 62:593-602.

LeDoux JE, Iwata J, Cicchetti P, Reis DJ (1988) Different projections of the central amygdaloid nucleus mediate autonomic and behavioral correlates of conditioned fear. J Neurosci 8:2517-2529.

Lister RG (1987) The use of a plus-maze to measure anxiety in the mouse. Psychopharmacology (Berl) 92:180-185.

McDonald AJ (1989) Coexistence of somatostatin with neuropeptide Y, but not with cholecystokinin or vasoactive intestinal peptide, in neurons of the rat amygdala. Brain Res 500:37-45.

McDonald AJ (2003) Is there an amygdala and how far does it extend? An anatomical perspective. Ann N Y Acad Sci 985:1-21.

McDonald AJ, Pearson JC (1989) Coexistence of GABA and peptide immunoreactivity in non-pyramidal neurons of the basolateral amygdala. Neurosci Lett 100:53-58.

Millan MJ (2003) The neurobiology and control of anxious states. Prog Neurobiol 70:83-244.

Nakajima M, Inui A, Asakawa A, Momose K, Ueno N, Teranishi A, Baba S, Kasuga M (1998) Neuropeptide Y produces anxiety via Y2-type receptors. Peptides 19:359-363.

Paxinos G, Franklin KBJ (2001) The mouse brain in stereotaxic coordinates, Ed 2. San Diego: Academic
Redrobe JP, Dumont Y, Herzog H, Quirion R (2003) Neuropeptide Y (NPY) Y2 receptors mediate behaviour in two animal models of anxiety: evidence from Y2 receptor knockout mice. Behav Brain Res 141:251-255.

Sainsbury A, Schwarzer C, Couzens M, Fetissov S, Furtinger S, Jenkins A, Cox HM, Sperk G, Hökfelt T, Herzog H (2002) Important role of hypothalamic Y2 receptors in body weight regulation revealed in conditional knockout mice. Proc Natl Acad Sci U S A 99:8938-8943.

Sajdyk T, Johnson P, Fitz S, Shekhar A (2008) Chronic inhibition of GABA synthesis in the bed nucleus of the stria terminalis elicits anxiety-like behavior. J Psychopharmacol 22:633-641.

Sajdyk TJ, Schober DA, Smiley DL, Gehlert DR (2002) Neuropeptide Y-Y2 receptors mediate anxiety in the amygdala. Pharmacol Biochem Behav 71:419-423.

Schmued LC, Stowers CC, Scallet AC, Xu L (2005) Fluoro-Jade C results in ultra high resolution and contrast labeling of degenerating neurons. Brain Res 1035:24-31.

Sosulina L, Schwesig G, Seifert G, Pape HC (2008) Neuropeptide Y activates a G-protein-coupled inwardly rectifying potassium current and dampens excitability in the lateral amygdala. Mol Cell Neurosci 39:491-498.

Stanić D, Brumovsky P, Fetissov S, Shuster S, Herzog H, Hökfelt T (2006) Characterization of neuropeptide Y2 receptor protein expression in the mouse brain. I. Distribution in cell bodies and nerve terminals. J Comp Neurol 499:357-390.

Steru L, Chermat R, Thierry B, Simon P (1985) The tail suspension test: a new method for screening antidepressants in mice. Psychopharmacology (Berl) 85:367-370.

Swanson LW, Petrovich GD (1998) What is the amygdala? Trends Neurosci 21:323-331.

Tasan RO, Lin S, Hetzenauer A, Singewald N, Herzog H, Sperk G (2009) Increased novelty-induced motor activity and reduced depression-like behavior in neuropeptide Y (NPY)-Y4 receptor knockout mice. Neuroscience 158:1717-1730.

Tschenett A, Singewald N, Carli M, Balducci C, Salchner P, Vezzani A, Herzog H, Sperk G (2003) Reduced anxiety and improved stress coping ability in mice lacking NPY-Y2 receptors. Eur J Neurosci 18:143-148.

Wahlestedt C, Pich EM, Koob GF, Yee F, Heilig M (1993) Modulation of anxiety and neuropeptide Y-Y1 receptors by antisense oligodeoxynucleotides. Science 259:528-531.

Wang JW, David DJ, Monckton JE, Battaglia F, Hen R (2008) Chronic fluoxetine stimulates maturation and synaptic plasticity of adult-born hippocampal granule cells. J Neurosci 28:1374-1384.

Zolotukhin S, Potter M, Zolotukhin I, Sakai Y, Loiler S, Fraites TJ Jr, Chiodo VA, Phillipsberg T, Muzyczka N, Hauswirth WW, Flotte TR, Byrne BJ, Snyder RO (2002) Production and purification of serotype 1, 2, and 5 recombinant adeno-associated viral vectors. Methods 28:158-167. 